\title{
Different Effects of Learning Methods And Eye Coordination On Takraw Learning Outcomes In PKO FIK UNIMED Students In 2020
}

\author{
$1^{\text {st }}$ Ibrahim Wiyaka ${ }^{1}$ \\ \{Ibrahimwiyaka10@gmail.com\}
}

Sports Coaching Education of Faculty of Sport Science Universitas Negeri Medan Jl. William Iskandar Ps. V, Kenangan Baru, Kec. Percut Sei Tuan, Kabupaten Deli Serdang, SUMUT $^{1}$

\begin{abstract}
The purpose of this study was to determine different effects of learning methods and eye coordination on Takraw learning outcomes in PKO FIK UNIMED students in 2020. The study used experimental methods. Population of this study was all 150 students of PKO FIK UNIMED who took advanced sepak takraw courses and sample is 100 people were taken by purposive sampling technique. The data analysis technique used statistical analysis, while the calculations used a difference test with a factorial. The results of the study show (1)There is a difference in the effect of the learning method between the ball tied with a rope and the ball hanging on the learning outcomes of Sepaksila (2)There is a difference in the effect of high eye-foot coordination and low eye-foot coordination on Sepaksila learning outcomes (3) There is an interaction between eye-foot coordination and Sepaksila learning outcomes.
\end{abstract}

Keywords: Learning Method, Eye-Foot Coordination, Sepaksila, Takraw

\section{Introduction}

To play sepak takraw well, one must have good abilities or skills. An important ability and very necessary to be possessed by a takraw player is the basic ability to play sepak takraw. The ability in question is kicking with parts of the feet, playing the ball with the head (playing the head), playing the ball with the chest, playing the ball with the thigh, playing the ball with the shoulder. In addition, takraw players must also be able to master basic techniques and special skills such as sepaksila, passing, smash, and block (holding).

Of the many basic techniques in the game of sepak takraw, this study only examines the problem of basic sepaksila techniques because this technique is the most important technique because it is mostly done when playing. Good at defending, arranging attacks and bait for smashes. To be able to do good sepaksila, you need the right starting attitude, good and maintained body balance to hold the ball, good coordination and the right starting attitude will produce good sepaksila.

Coordination is a very complex biomotor ability. Coordination is closely related to speed, strength, endurance and flexibility, so it is very much needed in almost every sport, the need for coordination in sports also trains the motor skills of athletes to always move according to what is ordered. Based on the above opinion, it can be concluded that coordination is an ability to combine several movements without tension, in the right order that is carried out 
smoothly without excessive use of energy. So that coordination is very useful and has an important role in implementing sepaksila in the game of sepak takraw.

To produce a better kick, it is necessary to coordinate the movement of the foot with the visual. Eye-foot coordination when kicking sepaksila is an ability to combine visual perception with foot movements into a special movement pattern, namely kicking the target object in the form of a ball. A player who does not have a good level of coordination will not produce a good quality and profitable kick in a game. The object used in the form of a ball is a moving object, the player at the time of kicking the ball is in an active state, so that players who perform sepaksila have a high level of difficulty but must have relatively high kick accuracy, so players must be good at combining visual perception, foot movements and feeling of motion. If the combination of several movements is less successful, then the results of the kicks are also unsatisfactory. Furthermore, regarding the indicators of coordination, Sukadiyanto [1], states that the main indicators of coordination are accuracy and economic movement. ${ }^{1}$

Sepaksila or playing the ball was originally a basic technique of receiving the ball. But at this point, it's basically sepaksila that becomes the basis as a technique for defending and lifting the ball/bait to attack. Errors or failure of the team in performing sepaksila will be detrimental because they cannot build attacks into the opponent's area. Players should be able to make good kicks and be able to direct the ball to a friend who will smash. Whether or not the bait is given will affect the quality of the smash made. According to Wiyaka [2] in his book "The basic technique of kicking consists of: a) Sepaksila, b). Turtle kick, c) Pinch kick, d) simpuh kick, e) Kick start, f) Foot kick" ${ }^{2}$. Of the various kicking techniques available, but in this study only limited to the sepaksila technique.

\section{Theory}

Sepaksila is the most dominant basic technique in the Sepaktakraw game, so some people call the sepaksila technique the mother of the Sepaktakraw game. Sepaksila is kicking the ball with the inside of the foot, which when kicking the foot the position of the foot is like a crosslegged person. Sepaksila is used to receive, hold and control the ball, pass, deliver the ball and to save the opponent's attack.

Techniques for Doing Sepaksila

a. The starting stance is standing with your feet shoulder-width apart

b. The kicking leg (sepaksila) is moved to fold (sila) at the knee level of the pedestal, with the axis of the stroke at the groin, while the pedestal is relaxed slightly bent.

c. The distance of the ball to the body is kept no more than half of our arms, because we hit with the foot position of the precepts. So the distance between the body and the ball is close.

d. The ball is hit with the inside of the foot facing up, the ankle is not weak for the power of the stroke and so that the ball does not spin when it is hit.

e. Body slightly bent forward and eyes toward the ball.

f. Both hands are bent at the elbows and opened at the sides of the body, this is to maintain balance.

${ }^{1}$ Sukadiyanto. Pengantar Teori dan Metodologi Melatih Fisik. Yogyakarta: PKO FIK UNY; 2002. 139

${ }^{2}$ Wiyaka, Sepak Takraw. FIK-UNIMED; 2020. 64 
g. At the time of impact of the ball (impact), the ankle is tensed and the foot is straightened.

h. The ball is kicked up over the head. The height of the ball is very dependent on the strength of the hitting foot and the bending of the fulcrum at the start of hitting.

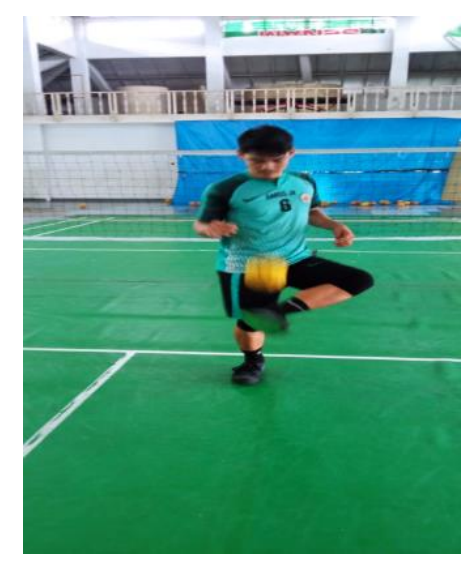

Fig.1. Sepaksila techniques.

Common Mistakes in Performing Sepaksila Techniques

a. The pedestal is not bent slightly, as a result, the striking foot cannot perform a perfect precept, the inside of the foot drops facing forward not upward.

b. When hitting the ball the ankle is not stiffened (tensioned), as a result the stroke is not powerful and the ball spins.

c. The attitude of the body when the blow is too bent, as a result the ball hits the mouth or face itself.

d. The ball is hit above the knee or the foot that is too high is chasing the ball that has not come down for the time to be hit.

Sepaksila Learning Method with Ball Tied with Rope

a. The ball is tied with a rope (the end of the rope is held)

b. Stand with your feet shoulder-width apart.

c. The fulcrum is slightly bent.

d. The ball is thrown up and kicked with the inside of the foot.

e. The body is upright, and rotates in the direction of the blow to keep balance.

f. Eyes on the ball.

g. The ankle when kicking the ball is tensed or hardened.

h. The direction of the shot can be changed - change right - left or accordingly hitting the foot with the ball.

Learning sepaksila with the ball tied with a rope has advantages and disadvantages. Based on its implementation, it can be analyzed regarding the advantages and disadvantages of sepaksila with the ball tied with a rope as follows:

Advantages of sepaksila ball tied with rope:

a. The ball can be kicked according to ability (high and low).

b. In addition to practicing sepaksila skills, it also trains reaction speed, because if you don't kick the ball, the ball will fall and rise after the rope is pulled. 
c. Fast motion (students move in which direction the ball is and can be controlled by the hand holding the rope.

Disadvantages of learning sepaksila with the ball tied with a rope:

a. For beginners it is difficult to make the right kick and timing This requires eye-foot coordination.

b. For beginners often hitting the ball with the foot does not fit, namely the ball away from the body.

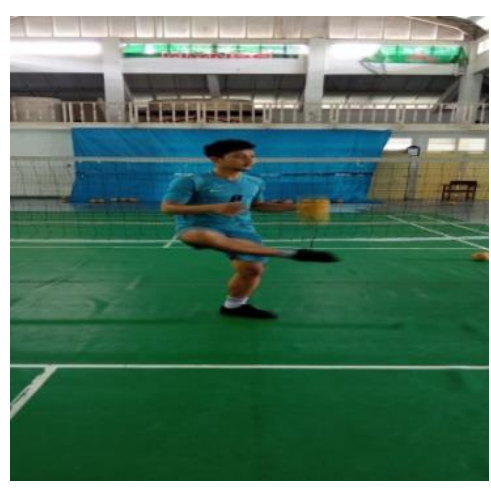

Fig. 2. Ball tied on sepaksila.

Hanging Sepak takraw Learning Method

a. The height of the ball hanging as high as $\pm 30 \mathrm{~cm}$ from the floor

b. Hanging height between $2.5 \mathrm{~m}-3 \mathrm{~m}$ from the floor

c. Players stand near the ball, in a ready position perform movements.

d. The ball that is kicked/sepaksila is stationary and does not move.

e. The direction of the kick must be up.

With the rope, the level of complexity can be reduced. The rope is used as a ball controller so that it doesn't move anywhere and the ball's height is fixed. The space for movement is more limited, so the ball control is tighter as a result, students have difficulty in kicking.

Based on its implementation, it can be analyzed the advantages and disadvantages of learning sepaksila with the ball hanging as follows:

The advantages of learning sepaksila with the ball hanging

a. Energy efficient, because of the rope to hang, the ball will back according to the maximum distance / rope length.

b. The frequency of the implementation of sepaksila is more, because the ball will return to the starting position due to the pull of the rope.

Disadvantages of learning sepaksila ball hanging:

a. The direction of the ball's motion is affected by the length of the string and area of contact with the foot and ball.

b. Slow motion (students just stand waiting for the ball to arrive because the ball is tied with a rope. 


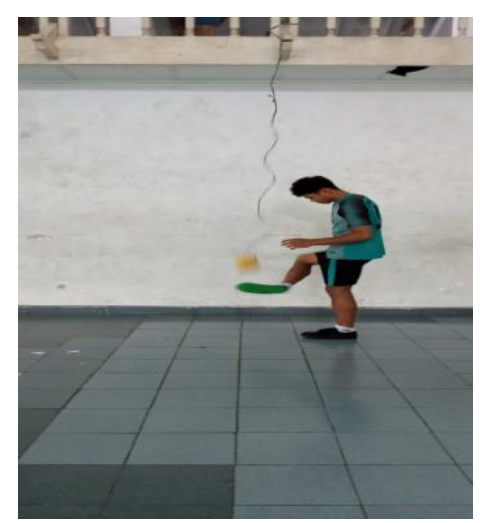

Fig. 3. Hanging ball techniques

\section{Research Methods}

The method used in this research is the experimental method. In this study, there were two experimental groups with different treatments. The first group was given sepaksila lessons with the ball hanging, while the second group was given sepaksila lessons with the ball thrown by itself. Differences in learning outcomes can be identified by testing the two groups with a sepaksila test.

According to Sugiyono [3] "population is a generalization area that consists of: objects / subjects that have certain quantities and characteristics set by the researcher to be studied and then withdrawn the conclusion"3. The population in this study were all students who were taking advanced sepak takraw courses totaling 150 people and sample in this study was 100 students taken by purposive sampling technique. The sample took part in the exercise 2 times a week for 3 months (18 meetings).

The research instrument is used to measure or find out the symptoms and properties of the variables studied. What is important is that the instrument must meet the criteria as a good instrument. Sugiyanto [4], states that, "Measurement instruments are said to be good if they meet the criteria: the measurement instrument must be valid, reliable, easy to administer and there are assessment norms ${ }^{4 "}$. Data collection techniques in this study by conducting tests on research variables. The tests used are: 1. Eye-foot Coordination Test ${ }^{5}$ [5] and 2. Sepaksila Skills Test.

\footnotetext{
${ }^{3}$ Sugiyono. Statistika untuk Penelitian. Bandung : CV Alfabeta;2019. 126

${ }^{4}$ Sugiyanto. Penelitian Pendidikan. Surakarta: Sebelas Maret University Press.;1993. 66

${ }_{5}^{5}$ Mulyono B. Tes dan Pengukuran Olahraga. Surakarta : Depdikbud RI Universitas Sebelas Maret Press;1992. 22
} 


\section{Research Results}

The description of the results of data analysis on sepak takraw abilities in lecture activities for PKO-FIK UNIMED students in 2020/2021 according to groups is presented in the form of a table as follows:

Table 1. Summary of descriptive statistics. ability data sepak takraw according to the research.

\begin{tabular}{cllllc}
\hline Treatment & $\begin{array}{l}\text { Reaction } \\
\text { Speed }\end{array}$ & Statistics & Pretest & Post Test & Enhancement \\
\hline Ball Held & $\begin{array}{l}\text { High } \\
\text { (B1) }\end{array}$ & Total & 361 & 465 & 104.0 \\
& & Mean & 14.4 & 18.6 & 4.2 \\
& SD & 1.5 & 1.4 & \\
& Low & Total & 197 & 323 & 126.0 \\
& (B2) & Mean & 7.9 & 12.9 & 5.0 \\
& & SD & 2.4 & 3.5 & \\
& Hanging Ball & Total & 360 & 435 & 75.0 \\
& High & Mean & 14.4 & 17.4 & 3.0 \\
& & SD & 1.6 & 1.3 & \\
& Low & Total & 199 & 309 & 110.0 \\
& (B2) & Mean & 8.0 & 12.4 & 4.4 \\
& & SD & 2.5 & 3.7 & \\
\hline
\end{tabular}

Based on the data description of the rope-tied ball learning method and the gagged ball learning method and the high level of eye-foot coordination and low eye-foot coordination showed: (1) When compared between the groups that received the sepaksila learning treatment with the ball tied rope method and the ball hung, it can be seen that the sepaksila learning group with the ball tied rope method was in the high coordination group. An increase of 104 in the ball group tied with rope. While the increase in the hanging ball group was 75 . The average increase was 4.16: 3. (2) When compared between the groups that received the sepaksila learning treatment with the ball tied rope method and the ball hung, it can be seen that the sepaksila learning group with the ball tied rope method was in the low coordination group. An increase of 126 in the ball group tied with rope. While the increase in the hanging ball group is 110 . The average increase is $5.04: 4.4$. (3) When compared between the sepaksila group who have high eye-foot coordination and those who have low eye-foot coordination, it is known that the group with high eye-foot coordination has an average increase of 4.6: 3.7. This means that the high coordination group has a greater improvement in sepaksila skills than the group with low eye-foot coordination.

\subsection{Differences in Effect Between Ball tied with a rope and ball hanging Against Sepak takraw Learning Outcomes.}


Based on the calculation results obtained $-\mathrm{p} 0.000<0.05$, it can be concluded that $\mathrm{H} 0$ is rejected and $\mathrm{Ha}$ is accepted, which means that there is a difference in the effect of high eyefoot coordination and low eye-foot coordination on sepak sila learning outcomes (tcount > ttable) $17,338>2.011$. From the data results show the ball tied with a rope is better than the ball hung. The reason is that the ball tied with a rope method allows students to adjust and follow the direction of the kick so that the ball can be kicked properly. In addition, when the ball is tied with a rope, eye-foot coordination must be required to react because otherwise the rope will stretch, causing the ball to be difficult to kick. Different things happen to the ball hanging, because the ball remains constant at a height, when there is no kick the ball will be stationary or moving according to the reach of the ball hanger strap. Then when kicked with a stronger kicking pressure the ball will return undirected due to the pull of the rope so that the ball is difficult to kick or control because sometimes it rotates which causes the ball to be unstable/normal.

\subsection{Differences in the Effect of High Eye-Foot Coordination and Low Eye-Foot Coordination on Sepak sila Learning Outcomes.}

Based on the calculation results obtained $-\mathrm{p} 0.000<0.05$, it can be concluded that Ho is rejected and $\mathrm{Ha}$ is accepted, which means that there is a difference in influence between the ball tied with a rope and the ball hanging on the learning outcomes of sepak sila. (Fcount > Ftable) $5.361>3.20$ ). The findings in this study explain that athletes who have high eye-foot coordination will be able to perform sepak sila better than those who have low eye-foot coordination. Students who have high eye-foot coordination will enable them to coordinate sepak sila movements more effectively and efficiently to direct/control the ball well. Thus it can be said that high eye-foot coordination is needed by every takraw athlete. Based on this, every athlete needs to have high eye-foot coordination to support sepak sila skills.

\subsection{Interaction between eye-foot coordination and ability Sepak Takraw}

Based on the calculation results obtained $-\mathrm{p} 0.000<0.05$, it can be concluded that Ho is rejected and $\mathrm{Ha}$ is accepted which means there is an interaction between eye-foot coordination and sepaksila ability on sepaktakraw. The adjusted R Square value of 0.545 means that there is an interaction of $54 \%$. Overall, it can be explained that after statistical testing of the empirical data that has been obtained from the field, it can be said that the proposed eye-foot coordination variable provides an interaction with the sepak takraw ability.

The level of coordination of a person's motion is a reflection of his ability to perform a movement smoothly, precisely and efficiently. A person with good coordination is not only able to perform a skill perfectly, but also can easily and quickly perform movement skills that are still new to him. With a good level of skill a person can change and move quickly from one movement pattern to another, so that by having a good level of movement coordination, the movement pattern becomes more efficient.

Thus, it can be explained the importance of having good eye-foot coordination so that it can improve the ability of sepak takraw, meaning that the better eye-foot coordination, the better the ability of sepak takraw. So that every sepak takraw athlete is expected to improve eye-foot coordination for good sepak sila results. 


\section{Conclusion}

According to the research and result there is a difference in the effect of sepak sila learning, hanging and hanging sepak sila balls the ball is thrown by itself on the results of learning sepak sila in sepak takraw for PKO FIK UNIMED students in 2020. There is a difference in the effect between high eye-foot coordination and low eye-foot coordination on sepak sila learning outcomes in sepak takraw game for PKO FIK UNIMED students in 2020. There is an interaction between the sepak sila learning method and eye-foot coordination in PKO-FIK UNIMED students 2020.

According to conclusion there is some suggestion : Teachers should strive to improve their abilities in developing materials, delivering materials, and in managing classes, so that the quality of their learning can continue to increase. And for effort to improve the learning outcomes of sepaksilka takraw, in addition to the application of appropriate learning methods, students must pay attention to the level of eye-foot coordination of students. Teachers and coaches are expected to apply the ball learning model tied with ropes to improve sepak sila learning outcomes.

\section{References}

[1] Sukadiyanto. Pengantar Teori dan Metodologi Melatih Fisik. Yogyakarta: PKO FIK UNY; 2002. 64.

[2] Wiyaka, Sepak Takraw. Medan:FIK- UNIMED; 2020. 22

[3] Sugiyono. Statistika untuk Penelitian. Bandung : CV Alfabeta; 2019. 126.

[4] Sugiyanto. Penelitian Pendidikan. Surakarta: Sebelas Maret University Press; 1993. 66.

[5] Mulyono B. Tes dan Pengukuran Olahraga. Surakarta : Depdikbud RI Universitas Sebelas Maret Press; 1992. 139. 